\author{
Postprint version \\ Journal website \\ : https://www.sciencedirect.com/science/article/pii/S0168851018306638 \\ ?via\%3Dihub \\ Pubmed link \\ : www.ncbi.nlm.nih.gov/pubmed/30528656 \\ DOI \\ : 10.1016/j.healthpol.2018.11.016
}

This is a Nivel certified Post Print, more info at nivel.nl

\title{
Trust in times of health reform
}

\begin{abstract}
Trust is seen as an important condition for the smooth functioning of institutions, such as the health care system. In this article we describe the trust relationships between the three main actors in the Dutch health care system: patients/insured, healthcare providers and insurers. We used data from different surveys between 2006 and 2016. 2006 was the year of the introduction of an insurance reform in the Netherlands towards regulated competition.

In the triangle of trust relationships between the three actors we found strong and mutual trust relationships between patients and healthcare providers and weak trust relationships between healthcare providers and insurers as well as between insured and insurance organisations. This hampers the intended role of insurers as selective purchasers of health care on the basis of quality and price.
\end{abstract}

\section{Background}

Smooth functioning of complex systems, such as health care systems, requires mutual trust between parties involved. As Gille et al. [1] state: '... many different aspects of the effective functioning of the health care system depend on the existence of a reasonable level of public trust in the system.' Trust between different actors in the healthcare system facilitate the cooperation, necessary to reach the goals of healthcare systems [2]. Gilson et al. [3] suggest that the mutual influences of patient-provider trust and organisational trust (i.e. the trust between healthcare providers and the organisations they work in) relate to healthcare performance and in particular responsiveness of healthcare. Public trust, especially related to information security and exchange, is seen as an important condition for the development of a learning health care system [4]. Trust might be even more important when reforms are implemented [5], which brings insecurity and changes in the power relations between major actors. Low public trust in times of reform might indicate a lack of legitimation [6].

In this article we describe public trust among different actors in the Dutch healthcare system since the health insurance reform of 2006 [7]. The health insurance reform, combined with the Healthcare Market Regulation Act, introduced a system of regulated competition [6]. This system assumes that insurers compete to attract insured; insurers selectively purchase care from healthcare providers and healthcare providers compete for patients. The relationships between the actors in a system of managed competition are based on contracts. These contracts are unavoidably incomplete [8], while the contractants lack important information, most notably about the quality of care. Trust between contract partners is required whenever contracts are incomplete [9]. 
Groenewegen, P.Groenewegen, P.P., Hansen, J., Jong, J.D. de. Trust in times of health reform. Health

Policy: 2019, 123(3), 281-287

Changes in the healthcare system, affecting the relationships between central actors, may impact trust among actors. This is illustrated by changes in US healthcare, where it has been suggested that privatisation and managed care threaten trust in healthcare institutions and healthcare providers $[10,11]$. Empirical research is, however, inconclusive. Kao et al. [12] showed a relationship between the way physicians are remunerated and patients' trust. Schlesinger et al. [13] showed that physicians judge for-profit health plans in the USA as less trustworthy, but empirical research on disclosure of the incentives HMO physicians receive, did not show an effect on trust of the insured in physicians or insurers [14].

The introduction of regulated competition in the Netherlands, although different from the illustrative examples in US healthcare, might affect and/or might be affected by three kinds of trust relationships in the healthcare triangle:

- $\quad$ trust between insured and insurers with a view of patients choosing an insurance carrier and an insurance policy;

- $\quad$ trust between healthcare insurers and providers who deal with each other on the healthcare purchasing market;

- $\quad$ trust between healthcare providers and patients in care provision.

The change in the relationships between insured and healthcare providers on the one hand and insurance organisations on the other may coincide with less trust as a consequence of increased uncertainty (in particular during the first years after the introduction of regulated competition). The relation between healthcare providers and patients is only expected to be affected when selective contracting would restrict insured in their choice of provider and when more (especially negative) information about performance would become available.

The regulated competition healthcare triangle is embedded in government regulation of the relationships between the actors and of the supervision of market regulation. Consequently, the trust relationships between government and regulators on the one hand and the actors in the healthcare triangle are also important; however, we don't have sufficient empirical data to go into these trust relationships.

The nature of the trust relationships may depend on characteristics of the relationships and the roles actors play in them. People and healthcare providers both act in two different roles; people act as patients who enter a largely implicit contract with healthcare providers and as insured who enter an insurance contract with an insurance organisation. Healthcare providers enter the treatment contract when they accept someone as a patient, and a purchasing contract when they enter a contract with an insurance organisation. The contract between patients and healthcare providers is (at least in the Dutch situation) institutionalised in law as the medical treatment contract, but in practice remains largely implicit. In insurance and purchasing contracts the emphasis is on a rational choice of conditions for reimbursement, volume of services and quality, and although this choice is characterised by uncertainty, the arrangements under these contracts are experience goods, i.e. their value can be evaluated after experience. The treatment that patients receive is different in that patients often don't know what care is best for them and are not able to evaluate whether or not it was the treatment that resulted in improvement of their health; in that sense healthcare is a confidence good [15].

Trust between the actors in the healthcare triangle may affect the effectiveness, efficiency and longevity of these relationships, quality of care, and overall success of policies [16]. The amount of trust in each of the three relationships most probably differs, partly depending on the different roles of actors, with most trust existing between patients and healthcare providers. This might influence the willingness of health insurers to take a strong role in the system, as they might fear that their actions in the relationship with providers (such as selective purchasing) or insured (channeling) collides with 
Groenewegen, P.Groenewegen, P.P., Hansen, J., Jong, J.D. de. Trust in times of health reform. Health

Policy: 2019, 123(3), 281-287

the stronger relationships between patients and providers. Empirical support for this is found in research on channeling $[17,18]$ and choice of health care provider [19].

Most research on trust focuses on interpersonal trust between patients and healthcare providers $[11,20]$. Although interpersonal trust may also affect the functioning of healthcare systems and in turn be affected by it, we focus on public (or institutional) trust in healthcare, i.e. the trust we place in categories of actors, institutions or the healthcare system [21]. Reason for this is that we are investigating trust during a period of institutional change and that the actors within the healthcare system usually have to deal with several other actors.

What is known about trust in each of these relations?

There is not much research that specifically focusses on the trust relations between insured persons and insurers, apart from the measurement of trust in insurers [[22], [23], [24]]. People in Australia chose private insurance based on trust (and long-standing relations) rather than based on risk calculation, costs and potential benefits [25]. The long-standing relation with an insurer is also related to trust in the USA context, but also past experience (having had disputes) and satisfaction play a role [26]. In the context of managed care, trust of insured in their insurers seems to be related to the perceptions of insured about the relationships between insurers and health care providers (the extent to which people see health care providers as influenced by the insurance organisations) [27].

Even less research has focussed on the trust relationships between care providers and insurers. Physicians in Korea have very little trust in the national insurance organisation that reviews the claims for reimbursement of the physicians [28]. Schlesinger at [13], in a study of physician judgements of the trustworthiness of health plans in the USA, found that non-profit health plans, smaller health plans and health plans that operated in a mixed market environment of for-profit and not-for-profit plans, were seen as more trustworthy.

Most research, however, has been devoted to trust relationships between care providers and patients. This is mainly about interpersonal trust between a patient and a care provider, but also about institutional trust in doctors in general, the medical profession or hospitals (see for an overview [29]). For all three trust relationships, existing research is uni-directional. We are not aware of research into whether insurers trust insured (although insurers seem to invest a lot in tracking down insurance fraud in indemnity insurance) and healthcare providers, and into whether healthcare providers trust patients.

In this article we will answer the following research questions:

1. How strong are the bi-directional trust relations between care providers and insurers, between patients and care providers, and between insured and insurers?

2. Have these relationships changed over time since the introduction of regulated competition in The Netherlands?

\section{Data and methods}

The data presented in this article, have been collected in several projects, at different times and with different measurement instruments, samples and methods. We will briefly discuss all data sources (Table 1).

\section{[Table 1]}

\subsection{Healthcare providers and insurers}

Healthcare providers of five professional backgrounds (hospital specialists, general practitioners, physiotherapists, pharmacists and dentists) received a mailed survey in 2006 and a web-questionnaire in 2014. Trust in health insurers was asked through two questions; one asking for their trust in the competence of health insurers and one asking for trust in the good intentions, each with answering categories 'very high', 'high', 'neither low, nor high', 'low' or 'very low' (see $[29,30]$ for this distinction). 
Groenewegen, P.Groenewegen, P.P., Hansen, J., Jong, J.D. de. Trust in times of health reform. Health

Policy: 2019, 123(3), 281-287

Especially in the field of economic transactions, where care purchasing by insurers belongs to, this seems a valuable distinction: can partners in a transaction deliver what was agreed and will they do it without strategic behaviour.

To measure trust of insurers in healthcare providers, care purchasers at the four biggest insurers which insure more than $80 \%$ of the Dutch population, were asked to fill in a web-questionnaire in 2016. Care purchasers play a pivotal role in insurance organisations under regulated competition. Purchasers also received two questions: their level of trust in the competence of healthcare providers, and their level of trust in the good intentions of healthcare providers, using the same answering categories as were presented to providers. As we distinguished between five types of healthcare providers, questions were asked for each of these five separately, hospital specialists, general practitioners, physiotherapists, pharmacists and dentists.

\subsection{Patients and providers}

Trust of patients in healthcare providers was measured by single questions, asking about the extent to which people trust different types of healthcare professions and institutions. Respondents could indicate per type of profession or institution whether their trust in them was 'very high', 'high', 'low' or 'very low'. They could also indicate whether they had no opinion. These questions have been asked every two years since 1997 in the Dutch Healthcare Consumer Panel [31]. In this study we report the trend from 2006 to 2014.

Trust of healthcare providers in their patients was measured in the same questionnaire to the five healthcare professions who were also asked about trust in health insurers in 2006 and 2014. Trust was measured by a scale consisting of two items:

- I can rely on patients giving me all the information I need to determine my treatment

- I can rely on patients not directly moving to another doctor in case of a disagreement.

For each item respondents could indicate in five categories whether they (fully) agreed or disagreed, or whether they were neutral. This scale was developed for the 2006 survey by the authors. In this study both items were displayed separately as the correlation between both elements was relatively low (.40).

\subsection{Insured and insurers}

Members of the same Dutch Health Care Consumer Panel were also asked about their trust in insurance organisations. This question was only available every two years as of the year 2012 . We used a single question asking about the extent to which people trust health insurers, using the same categories as for the trust of patients in health care providers ('very high', 'high', 'low' or 'very low'). The extent to which insurers trust insured was asked among care purchasers in 2016, as part of the same web-questionnaire which also contained questions on their trust in healthcare providers. Purchasers answered two questions: their level of trust in the competence of insured, and their level of trust in the good intentions of insured.

\subsection{Data analysis}

Data were analysed using Stata/SE, version 14.2 for Windows. Significance tests of differences between years in the data of health insurers and health care providers were conducted using chisquare tests, in all cases with a dichotomisation of the highest categories ('(very) high' or '(fully) agree' compared to the other categories). Full results are displayed in a webannex. Significance tests for patients/insured were conducted by means of a trend analysis, using logistic regression. As for comparability of data sources over the years, the survey among patients/insured is structured in the same manner in all years and using the same sampling format. Weights were used to create a representative sample in comparison to the Dutch population based on age and gender. In comparison, the survey method among health care providers does differ per year: written surveys in 
Groenewegen, P.Groenewegen, P.P., Hansen, J., Jong, J.D. de. Trust in times of health reform. Health

Policy: 2019, 123(3), 281-287

2006 versus online surveys in 2014 and also the type of approach differs. At the same time, the order and formulation of survey questions was very similar, and the same applies to response rates. For the 2006 data set, results were weighted in order to match the population according to type of practice. For the 2014 data set, no weighting was used as the composition of the sample was very similar to that of the entire population (except for physiotherapists who were more often self-employed than in the population). Last, no weights were used in the dataset of insurers, as no background information on the entire population was available.

\section{Results}

\subsection{Healthcare providers and insurers}

The most recent measurement shows that care purchasers at insurance organisations have the highest trust in the good intentions of GPs and in the expertise of medical specialists (Table 2). For all providers they have more trust in their expertise than in their good intentions. Providers' trust in insurers, at the most recent measurement, is very low with percentages of (very) high trust ranging between 2 and $4 \%$. This is much lower than the trust care purchasers place in these providers. For care purchasers we have only one measurement, but for healthcare providers we have two, one at the introduction of regulated competition and one nearly ten years later. Between 2006 and 2014, trust of providers seems to have decreased for most professions (except GPs), but this is only significant in the case of physiotherapists.

\section{[Table 2]}

\subsection{Patients and providers}

Trust of providers in their patients differed a bit according to the indicator used, but for both indicators the level of trust of pharmacists was lowest (Table 3). There were some minor fluctuations over time, but only one was significant: in 2006 more medical specialists trusted on receiving the right information as compared to 2014 (48\% versus 35\%).

Vice versa, trust of patients in providers is in general very high. There is a small significant decline over time for all types of providers and in particular for pharmacists.

\section{[Table 3][Figure 1]}

\subsection{Insured and insurers}

People's trust in health insurers is relatively low. It has been measured three times now: in $201231 \%$ indicated they had high or very high trust in health insurers (Fig. 1). Over time there is a slight decrease to $26 \%$ in 2014 and $27 \%$ \% in 2016 (not in table).

Insurers' trust in insured was only measured once, in 2016, and is 61\% for trust in insured persons' good intentions and $9 \%$ when it comes to their competences. (not in table).

\section{Discussion}

In this article we have described the current level of public trust in healthcare and changes over time among the three main actors in the Dutch health care system. For the current levels of trust, it turns out that patients trust in healthcare providers is high, but slightly decreasing, while trust of health care providers in patients (measured in a different form) is lower and unchanged. Trust of healthcare providers in insurers is very low and trust of insured people in insurers is also low. The other way around, trust of insurers in insured persons and providers is much higher. 
Groenewegen, P.Groenewegen, P.P., Hansen, J., Jong, J.D. de. Trust in times of health reform. Health

Policy: 2019, 123(3), 281-287

Changes over a period in which the health care system was transformed from government planning to regulated competition were small. Unfortunately, we only have one measurement of care purchasers' trust in providers and in insured people.

It seems that the mutual trust between health care providers and their patients has not been affected strongly by the introduction of regulated competition. As a consequence, the triadic relationships between insurers, healthcare providers and people in their roles as patients and insured persons are out of balance. This might be a reason for the (until yet) lack of success of one of the building blocks of managed competition, namely selective purchasing of care. The low level of trust of healthcare providers in insurers might be related to specific actions of insurers and the uncertainties that market reforms bring by. Market oriented reforms may have led to shifts in power between the main actors, including the government, as is the case with market transitions in other fields of society [32].

We are aware that trust may not have the same meaning in each of the relationships [15]. In the trust relation between health insurers on the one hand and providers and insured on the other, the cognitive-rational aspects of trust are probably more important than the affective aspects, whilst in the patient-provider relationship the balance is more towards the affective aspects [2]. However, the measurements we could use in this study also differ in the aspects that they trigger. Trust of patients in healthcare providers is measured by a single, neutral item, while trust of providers in patients is measured by two items that trigger the good intentions aspect of trust. Research also suggests that insureds' trust in a health insurer is more related to satisfaction (which is basically founded on past experience; an insurance policy is an experience good) than trust in a physician or trust in the medical profession (where experience with treatment still leaves the question whether treatment result is directly related to the treatment) [26]. Patients' trust in healthcare providers is perhaps closer to interpersonal trust than trust in a more abstract entity, such as hospitals or insurers.

A missing actor in the healthcare triad in this study is the government as regulator of the system. We don't have sufficient empirical data on trust in government as related to its role in healthcare. However, over time public trust in government and major political institutions has been measured [33]. Public trust in government, politics and parliament is low and volatile, and there is a decreasing trend in the period 2007-2017. It is perhaps less related to concrete experiences than trust in healthcare. Lack of trust in government might be an indicator of general feelings of discomfort in the population and as such have an influence on the trust relations in the healthcare triad [34]. Information about public trust is important, in general because lack of public trust in the health care system is associated with poorer health outcomes and less efficient use of health care $[21,29,35]$. Given the very low trust of health care providers in insurers and the relatively low trust of care purchasers of insurance organisations in the good intentions of some groups of providers, it is striking that the system of contracting is still functioning. At the same time, perhaps it could function much smoother and without less friction with more mutual trust. More specific for the relationships we described in this article, lack of trust in each of the three relations is associated with negative consequences:

- With lack of trust in the insured - insurer relationship people don't chose selective contracts and don't want to be channeled to preferred providers [17,36]. Balkrishnan et al. [37] found that HMO insured with higher trust in their primary care physician made less use of nonprimary care physicians.

- With lack of trust in the provider - insurer relationship, contracting is more difficult and requires more monitoring $[30,38]$. And more monitoring may lead to less trust and less job satisfaction of care providers [28]. A movement among healthcare provider to reduce the administrative pressures (among others related to the insurance contracts) came up in 2015. Insurance organisations and government (and its supervising institutions) support a reduction of monitoring information. 
Groenewegen, P.Groenewegen, P.P., Hansen, J., Jong, J.D. de. Trust in times of health reform. Health

Policy: 2019, 123(3), 281-287

- With lack of trust in the patient - provider relationship, there is less compliance with therapy and shared decision-making (see e.g. the literature review in [29]).

Although public trust in health care providers and institutions was high and only slightly decreasing, other research around the development of public trust in the wake of an incident in a Dutch hospital has shown that public trust was affected and that it takes quite some time to recover trust $[39,40]$. Nevertheless, there still is a need for more research '... into the understanding, protection and recovery of trust in health care systems, not only for the effective functioning of health care systems but also for society in general.' [41].

Part of the Dutch health care reform towards regulated competition is an increasing emphasis on transparent information about the performance of health care providers and accountability of health care providers as well as health insurers. The lack of trust of insured in insurance organisations has been attributed to a 'credible commitment problem' [17]. Insured don't trust insurance organisations to act in the interest of the insured in their purchasing strategies, because they lack the quality information to select the best available care for their insured. In the relationship between insured persons and insurance organisations, trust may increase with more transparency about the purchasing strategy of insurers about the quality of the providers they select. However, patients have a high level of trust in healthcare providers, also in the absence of transparent information on quality. It has been suggested that transparency and accountability might lead to less institutional trust in healthcare providers with the general public $[9,21,42,43]$.

Trust is usually described as a beneficial phenomenon. However, we have to be aware of possible negative consequences of trust when close relations of trust lead towards closure of networks, an internal orientation and less oversight $[44,45]$.

What can insurance organisations do to increase trust of the insured and health care providers in them? According to Van der Schee [21] public trust is built on three pillars: institutional guarantees, information from third parties (news media, people's networks) and personal experiences. With respect to institutional guarantees, the formal requirement of participation of insured in policies of the insurer and upcoming Dutch legislation to give insured more influence on the purchasing policies of insurers maybe actively taken up by insurers. Information from third parties is difficult to influence by insurers. However, personal experiences both of insured and health care providers can be influenced by the behaviour of insurers. Insurance organisations experiment with more freedom for contracted health care providers. The process to come to these experiments involves a lot of deliberation and in this process trust may be built. Additionally, literature on attempts to increase trust between patients and doctors suggest that patient participation and shared decision-making only contributes to more trust if participation and shared decision-making are congruent with the values of patients [29]. Value congruence also seems to play a role in explaining public trust in the health care system and actors within the system [46] and might consequently be relevant in attempting to improve the trust relations between insurers on the one hand and insured and providers on the other hand.

\subsection{Strengths and limitations}

The strength of this article is that we studied trust in three relationships and where possible over time. A limitation is that trust was measured in diverse ways and not based on one unifying theoretical approach, although the types of survey questions were kept identical in different rounds. It may e.g. be that confirmation or strategic bias occurs, e.g. by downplaying the trust in other parties within the health system. It is for this reason that it is recommended to continue monitoring trust in the future, preferably using similar sampling designs. Last, we did not have data on trust of insurers in healthcare providers at the start of regulated competition and only three, rather recent measures of trust of insured in insurance organisations. 
Groenewegen, P.Groenewegen, P.P., Hansen, J., Jong, J.D. de. Trust in times of health reform. Health

Policy: 2019, 123(3), 281-287

We cannot make a strong claim as to the relationship between the introduction of regulated competition in Dutch health care and trust in the relationships in the health care triangle. Low trust of insured persons and healthcare providers in insurance organisations may be related to the role of insurance organisations in the healthcare system in general and not so much to the changes in their relationships to insured and healthcare providers. There is a complicated, mutual relationship between changes in society in general, changes in the health care system and in the day-to-day provision of health care and public trust. Moreover, there seem to be fluctuations, if not a decline, in public trust in democratic institutions, the value of scientific knowledge etc. in Western societies $[47,48]$. This could be an alternative explanation of low trust and the decrease of trust in some of the relations described in this article.

\subsection{Conclusion}

Based on the outcomes of this study, we can say that the trust relationships between the main actors of the system are out of balance. Health insurers don't receive much trust from their insured and very little trust from providers, while the trust relations between patients and providers are strong. After ten years of regulated competition, the trust relations between providers and insurers have not stabilised at a reasonably high level. This might have led to hidden costs of contracting and monitoring in the system. It also makes it more difficult to have the insurance organisations play the role that was intended in the system: being a selective purchaser, based on price and quality. Given the strong trust relations between patients and providers, selective purchasing is a risky strategy.

\section{Conflict of interest}

None.

\section{Acknowledgements}

The data used in this article are from several sources. The Dutch Healthcare Consumer Panel is funded by the Ministry of Health through the institutional subsidy to NIVEL; data collection among healthcare providers was subsidised by VVAA; data collection among health insurance purchasers was funded from own means of NIVEL.

\section{References}

[1] F. Gille, S. Smith, N. Mays Towards a broader conceptualization of 'public trust' in the health care system Social Theory \& Health (2016), 10.1057/s41285-016-0017-y

[2] L. Gilson Trust and the development of health care as a social institution Social Science \& Medicine, 56 (7) (2003), pp. 1453-1468, 10.1016/S0277-9536(02)00142-9

[3] L. Gilson, N. Palmer, H. Schneider Trust and health worker performance: exploring a conceptual framework using South African evidence Social Science \& Medicine, 61 (7) (2005), pp. 1418-1429, 10.1016/j.socscimed.2004.11.062

[4] C. Grossmann, B. Powers, J.M. McGinnis (Eds.), Digital infrastructure for the learning health system: the foundation for continuous improvement in health and health care. institute of medicine (workshop series), the National Academies Press, Washington DC (2011)

[5] F. Heinemann, B. Tanz The impact of trust on reforms Journal of Economic Policy Reform, 11 (2008), pp. 173-185, 10.1080/174878708024053753

[6] H. Maarse, P. Jeurissen, D. Ruwaard Results of the market-oriented reform in the Netherlands: a review Health Economics, Policy and Law (2016), 10.1017/S1744133115000353

[7] M. Kroneman, W. Boerma, M. van den Berg, P. Groenewegen, J. de Jong, E. van Ginneken The Netherlands: health system review Health Systems in Transition, 18 (2) (2016), pp. 1-239 2016 
Groenewegen, P.Groenewegen, P.P., Hansen, J., Jong, J.D. de. Trust in times of health reform. Health Policy: 2019, 123(3), 281-287

[8] O.E. Williamson The theory of the irm as governance structure: from choice to contract Journal of Economic Perspectives, 16 (3) (2002), pp. 171-195

[9] A. Maynard, K. Bloor Trust and performance management in the medical Marketplace Journal of the Royal Society of Medicine, 96 (2003), pp. 532-539

[10] D. Mechanic The functions and limitations of trust in the provision of medical care Journal of Health Politics, Policy and Law, 23 (4) (1998), pp. 661-686, 10.1215/03616878-23-4-661

[11] J. Abelson, F.A. Miller, M. Giacomini What does it mean to trust a health system? A qualitative study of Canadian health care values Health Policy, 91 (2009), pp. 63-70

[12] A. Kao, D.C. Green, A.M. Zaslavsky, J.P. Koplan, P.D. Cleary The relationship between method of physician payment and patient trust Journal of the American Medical Association, 280 (19) (1998), pp. 1708-1714

[13] M. Schlesinger, N. Quon, M. Wynia, D. Cummins, B. Gray Profit-seeking, corporate control, and the trustworthiness of health care organizations: assessments of health plan performance by their affiliated physicians Health Services Research, 40 (3) (2005), pp. 605-646

[14] M.A. Hall, E. Dugan, R. Balkrishnan, D. Bradley How disclosing HMO physician incentives affects trust Health Affairs, 21 (2) (2002), pp. 197-206, 10.1377/hlthaff.21.2.197

[15] W. Arts, R. Batenburg, P. Groenewegen (Eds.), Een kwestie van vertrouwen: over veranderingen op de makt voor professionele diensten en in de organisatie van vrije beroepen [a question of trust: on changes on the market for professional services and the organisation of liberal professions], Amsterdam University Press, Amsterdam (2001)

[16] A.S. Wilk, J.E. Platt Measuring physicians' trust: a scoping review with implications for public policy

Social Science \& Medicine, 165 (2016), pp. 75-81

[17] L. Boonen, F. Schut Preferred providers and the credible commitment problem in health insurance: first experiences with the implementation of managed competition in the Dutch health care system Health Economics, Policy and Law, 6 (2011), pp. 219-235

[18] R.E. Bes, E.C. Curfs, P.P. Groenewegen, J.D. De Jong Selective contracting and channeling patients to preferred providers: a scoping review Health Policy, 121 (2017), pp. 504-514

[19] M. Tai-Seale, B. Pescosolido The Public's Opinions of Physicians: Do Perceived Choice and Exercised Choice Matter? American Journal of Managed Care, 9 (2003), pp. 631-638

[20] S. Ozawa, P. Sripad How do you measure trust in the health system? A systematic review of the literature Social Science and Medicine, 91 (2013), pp. 10-14

[21] E. Van der Schee Public trust in health care: exploring the mechanisms PhD thesis Utrecht University, Utrecht: NIVEL (2016)

[22] B. Zheng, M.A. Hall, E. Dugan, K.E. Kidd, D. Levine Development of a scale to measure patients' trust in health insurers Health Services Research, 37 (2002), pp. 185-200

[23] M. Hendriks, D.M.J. Delnoij, P.P. Groenewegen Het meten van vertrouwen in de zorgverzekeraar: psychometrische eigenschappen van een Nederlandse vragenlijst [Measuring trust in health insurers: psychometric properties of a Dutch survey TSG Tijdschrift voor Gezondheidswetenschappen, 85 (2007), pp. 280-286

[24] S.D. Goold, D. Fessler, C.A. Moyer A measure of trust in insurers Health Services Research, 41 (2006), pp. 58-78

[25] K. Natalier, K. Willis Taking responsibility or averting risk? A sociocultural approach to risk and trust in private health insurance decisions Health, Risk \& Society, 10 (2008), pp. 399-411

[26] R. Balkrishnan, E. Dugan, F.T. Camacho, M.A. Hall Trust and satisfaction with physicians, insurers, and the medical profession Medical Care, 41 (2003), pp. 1058-1064

[27] S.D. Goold, G. Klipp Managed care members talk about trust Social Science \& Medicine, 54 (2002), pp. 879-888

[28]

H.Y. Lee, S.E. Park, E.C. Park, M.I. Hahm, W.H. Cho 
Groenewegen, P.Groenewegen, P.P., Hansen, J., Jong, J.D. de. Trust in times of health reform. Health Policy: 2019, 123(3), 281-287

Job satisfaction and trust in Health Insurance Review Agency among Korean physicians Health Policy, 87 (2) (2008), pp. 249-257, 10.1016/j.healthpol.2007.12.011

[29] M. Calnan, R. Rowe Trust in health care: an agenda for future research Nuffield Trust, London (2004)

[30] R. Batenburg, W. Raub, C. Snijders Contacts and contracts: dyadic embeddedness and the contractual behavior of firms Research in the Sociology of Organizations, 20 (2003), pp. 135-188

[31] A.E.M. Brabers, M. Reitsma-van Rooijen, J.D. De Jong Consumentenpanel Gezondheidszorg. Basisrapport met informatie over het panel 2015. [Healthcare Consumer Panel. Main report with information about the panel] NIVEL, Utrecht (2015)

[32] V. Nee A theory of market transition: from redistribution to markets in state socialism American Sociological Review, 54 (1989), pp. 663-681

[33] P. Dekker, P. Van Houwelingen Burgerperspectieven 2017/4: tien jaar Burgerperspectieven [Citizen perspectives 2017/4: ten years of Citizen Perspectives]. Den Haag Institute for Social Research, Netherlands (2017)

[34] P. Dekker, J. Den Ridder, P. Van Houwelingen, S. Kooiker Zorg en onbehagen in de bevolking [Care and discomfort in society]. Den Haag Institute for Social Research, Netherlands (2016)

[35] M. Mohseni, M. Lindstrom Social capital, trust in the health-care system and self-rated health: the role of access to health care in a population-based study Social Science \& Medicine, 64 (2007), pp. 1373-1383

[36] R.E. Bes, S. Wendel, E.C. Curfs, P.P. Groenewegen, J.D. De Jong Acceptance of selective contracting: the role of trust in the health insurer BMC Health Services Research, 13 (2013), p. 375

[37] R. Balkrishnan, M.A. Hall, S. Blackwelder, D. Bradley Trust in insurers and access to physicians: associated enrollee behaviors and changes over time Health Services Research, 39 (2004), pp. 813-823

[38] R. Gulati, J.A. Nickerson Interorganizational trust, governance choice, and exchange performance

Organization Science, 19 (5) (2008), pp. 688-708

[39] De Jong J.D. Van der Schee, P.P. Groenewegen The influence of a local, media covered hospital incident on public trust in health care European Journal of Public Health, 22 (2011), pp. 459-464

[40] De Jong J.D. Van der Schee, P.P. Groenewegen Eén jaar na problemen in een ziekenhuis: kan verloren vertrouwen worden herwonnen? [One year after problems in a hospital: can lost trust be regained? TSG Tijdschrift voor Gezondheidswetenschappen, 91 (2013), pp. 60-67

[41] F. Gille, S. Smith, N. Mays Why public trust in health care systems matter and deserves more research attention Journal of Health Services Research and policy, 20 (2015), pp. 62-64

[42] P. Meurs Sociaal vertrouwen [Social trust] SER/Verweij-Jonker Instituut (2008)

[43] R. Rowe, M. Calnan Trust relations in health care - the new agenda European Journal of Public Health, 16 (2006), pp. 4-6

[44] N.A.D. Connell, R. Mannion Conceptualisations of trust in the organisational literature. Some indicators from a complementary perspective Journal of Health Organization and Management, 20 (2006), pp. 417-433

[45] D. Latusek, K.S. Cook Trust in transitions Kyklos, 65 (2012), pp. 512-525

[46] S.M. Kehoe, J.R. Ponting Value importance and value congruence as determinants of trust in health policy actors Social Science \& Medicine, 57 (2003), pp. 1065-1075

[47] M. Bovens, A. Wille Falling or fluctuating trust levels? The case of the Netherlands S. Zmerli, M. Hooghe (Eds.), Political trust: why context matters, ECPR Press (2013)

[48] M. Torcal The decline of political trust in Spain and Portugal: Economic performance or Political responsiveness? American Behavioral Scientist, 58 (12) (2014), pp. 1542-1567. 
Groenewegen, P.Groenewegen, P.P., Hansen, J., Jong, J.D. de. Trust in times of health reform. Health

Policy: 2019, 123(3), 281-287

Tables and Figures

Table 1

Summary of data collection approaches.

\begin{tabular}{|c|c|c|c|c|c|}
\hline Trust of & Timing and method & Source population & Sample & Response & Measurement \\
\hline $\begin{array}{l}\text { Healthcare providers in } \\
\text { insurers }\end{array}$ & $\begin{array}{l}\text { Mailed survey } 2006 . \\
\text { Web survey } 2014\end{array}$ & $\begin{array}{l}\text { Working in one of five health } \\
\text { professions: GPs, pharmacists, } \\
\text { medical specialists, dentists } \\
\text { and physiotherapists }\end{array}$ & $\begin{array}{l}\text { In 2006, a written } \\
\text { questionnaires sent to } 1163 \\
\text { professionals, using different } \\
\text { sampling frames. } \\
\text { In } 2014 \text { a link to } \\
\text { web-questionnaire sent to } \\
6393 \text { professionals, all } \\
\text { members of a membership } \\
\text { organization (VvAA). }\end{array}$ & $\begin{array}{l}\text { In } 2006446 \text { respondents (38\%) } \\
\text { In 2014: } 2176 \text { respondents } \\
(34 \%)\end{array}$ & $\begin{array}{l}\text { Two items: how much trust do } \\
\text { you place in the good } \\
\text { intentions of health insurers } \\
\text { and how much trust do you } \\
\text { place in the competence of } \\
\text { health insurers? }\end{array}$ \\
\hline $\begin{array}{l}\text { Insurers in healthcare } \\
\text { providers }\end{array}$ & Web survey 2016 & $\begin{array}{l}\text { Care purchasers at four large } \\
\text { health insurers }\end{array}$ & $\begin{array}{l}\text { Link to web questionnaire sent } \\
\text { to } 162 \text { purchasers in the four } \\
\text { health insurance organisations }\end{array}$ & 72 care purchasers ( $44 \%)$ & $\begin{array}{l}\text { Ten items: how much trust do } \\
\text { you place in the good } \\
\text { intentions or competence of } \\
\text { pharmacists, GPs, medical } \\
\text { specialists, dentists, } \\
\text { physiotherapists }\end{array}$ \\
\hline $\begin{array}{l}\text { Patients in healthcare } \\
\text { providers }\end{array}$ & $\begin{array}{l}\text { Healthcare Consumer Panel, } \\
\text { mailed or web-survey, every } \\
\text { two years }\end{array}$ & $\begin{array}{l}\text { Cross-section of Dutch } \\
\text { population }\end{array}$ & $\begin{array}{l}\text { Questionnaire sent to } \\
1000-2250 \text { panel members }\end{array}$ & $\begin{array}{l}\text { Between } 44 \% \text { and } 84 \% \text { resulting } \\
\text { in } 840-1071 \text { respondents per } \\
\text { year }\end{array}$ & $\begin{array}{l}\text { Five items. How much trust do } \\
\text { you place in GPs, dentists, } \\
\text { pharmacists, medical } \\
\text { specialists and } \\
\text { physiotherapists }\end{array}$ \\
\hline $\begin{array}{l}\text { Healthcare providers in } \\
\text { patients }\end{array}$ & $\begin{array}{l}\text { Mailed survey } 2006 . \\
\text { Web survey } 2014\end{array}$ & $\begin{array}{l}\text { Working in one of five health } \\
\text { professions: GPs, pharmacists, } \\
\text { medical specialists, dentists } \\
\text { and physiotherapists }\end{array}$ & $\begin{array}{l}\text { In 2006, written questionnaires } \\
\text { sent to } 1163 \text { professionals, } \\
\text { using different sampling } \\
\text { frames. } \\
\text { In } 2014 \text { link to } \\
\text { web-questionnaire sent to } \\
6393 \text { professionals, all } \\
\text { members of a membership } \\
\text { organization (VvAA). }\end{array}$ & $\begin{array}{l}\text { In } 2006446 \text { respondents ( } 38 \%) \\
\text { In 2014: } 2176 \text { respondents } \\
(34 \%)\end{array}$ & $\begin{array}{l}\text { Two items: } \\
\text { 'I can rely on patients giving } \\
\text { me all the information I need } \\
\text { to determine my treatment' } \\
\text { and 'I can rely on patients not } \\
\text { directly moving to another } \\
\text { doctor in case of a } \\
\text { disagreement' }\end{array}$ \\
\hline Patients in insurers & $\begin{array}{l}\text { Healthcare Consumer Panel, } \\
\text { mailed or web survey, every } \\
\text { two years }\end{array}$ & $\begin{array}{l}\text { Cross-section of Dutch } \\
\text { population }\end{array}$ & $\begin{array}{l}\text { Questionnaire sent to } 1500 \text { - } \\
2250 \text { panel members }\end{array}$ & $\begin{array}{l}\text { Between } 44 \% \text { and } 58 \% \text { resulting } \\
\text { in } 803-985 \text { respondents per } \\
\text { year }\end{array}$ & $\begin{array}{l}\text { One item: How much trust do } \\
\text { you place in health insurers? }\end{array}$ \\
\hline Insurers in insured & Web survey 2016 & $\begin{array}{l}\text { Care purchasers at four large } \\
\text { health insurers }\end{array}$ & $\begin{array}{l}\text { Link to web questionnaire sent } \\
\text { to } 162 \text { purchasers }\end{array}$ & $72(44 \%)$ & $\begin{array}{l}\text { Two items: how much trust do } \\
\text { you place in the good } \\
\text { intentions or competence of } \\
\text { insured }\end{array}$ \\
\hline
\end{tabular}

Table 2

Insurers trust in providers (2016) and providers' trust in insurers (2014 and 2006).

Insurers trust in providers Providers trust in
insurers

\begin{tabular}{|c|c|c|c|}
\hline & \multirow[b]{2}{*}{2016} & \\
\hline & & 2014 & 2006 \\
\hline $\begin{array}{l}\text { General } \\
\text { practitioners } \\
\text { - expertise }\end{array}$ & $74 \%$ & $4 \%$ & $7 \%$ \\
\hline - good intentions & $61 \%$ & $3 \%$ & $1 \%$ \\
\hline $\begin{array}{l}\text { Medical specialist } \\
\text { - expertise }\end{array}$ & $86 \%$ & $3 \%$ & $5 \%$ \\
\hline - good intentions & $45 \%$ & $3 \%$ & $2 \%$ \\
\hline $\begin{array}{l}\text { Physiotherapists } \\
\text { - expertise }\end{array}$ & $53 \%$ & $4 \%$ & $7 \%$ \\
\hline - good intentions & $36 \%$ & $3 \%^{*}$ & $9 \%^{\circ}$ \\
\hline $\begin{array}{l}\text { Pharmacists } \\
\text { - expertise }\end{array}$ & $66 \%$ & $2 \%$ & $2 \%$ \\
\hline - good intentions & $17 \%$ & $4 \%$ & $6 \%$ \\
\hline $\begin{array}{l}\text { Dentists } \\
\text { - expertise }\end{array}$ & $56 \%$ & $3 \%$ & $6 \%$ \\
\hline - good intentions & $17 \%$ & $3 \%$ & $2 \%$ \\
\hline
\end{tabular}

" chi square sign $\mathrm{p}<0.01$. 
Groenewegen, P.Groenewegen, P.P., Hansen, J., Jong, J.D. de. Trust in times of health reform. Health

Policy: 2019, 123(3), 281-287

Table 3

Providers trust in patients (2006 and 2014).

\begin{tabular}{|c|c|c|c|c|}
\hline & \multicolumn{2}{|c|}{$\begin{array}{l}\text { I can rely on patients giving me all the } \\
\text { information I need to determine my } \\
\text { treatment }\end{array}$} & \multicolumn{2}{|c|}{$\begin{array}{l}\text { I can rely on patients not directly moving } \\
\text { to another doctor in case of a disagreemen }\end{array}$} \\
\hline & 2014 & 2006 & 2014 & 2006 \\
\hline General practitioners & $33 \%$ & $28 \%$ & $54 \%$ & $62 \%$ \\
\hline Medical specialist & $35 \%^{\circ}$ & $48 \%^{\circ}$ & $41 \%$ & $39 \%$ \\
\hline Physiotherapists & $45 \%$ & $43 \%$ & $44 \%$ & $42 \%$ \\
\hline Pharmacists & $16 \%$ & $16 \%$ & $34 \%$ & $40 \%$ \\
\hline Dentists & $32 \%$ & $33 \%$ & $45 \%$ & $59 \%$ \\
\hline
\end{tabular}

$\cdot$ chi square sign $\mathrm{p}<0.01$.

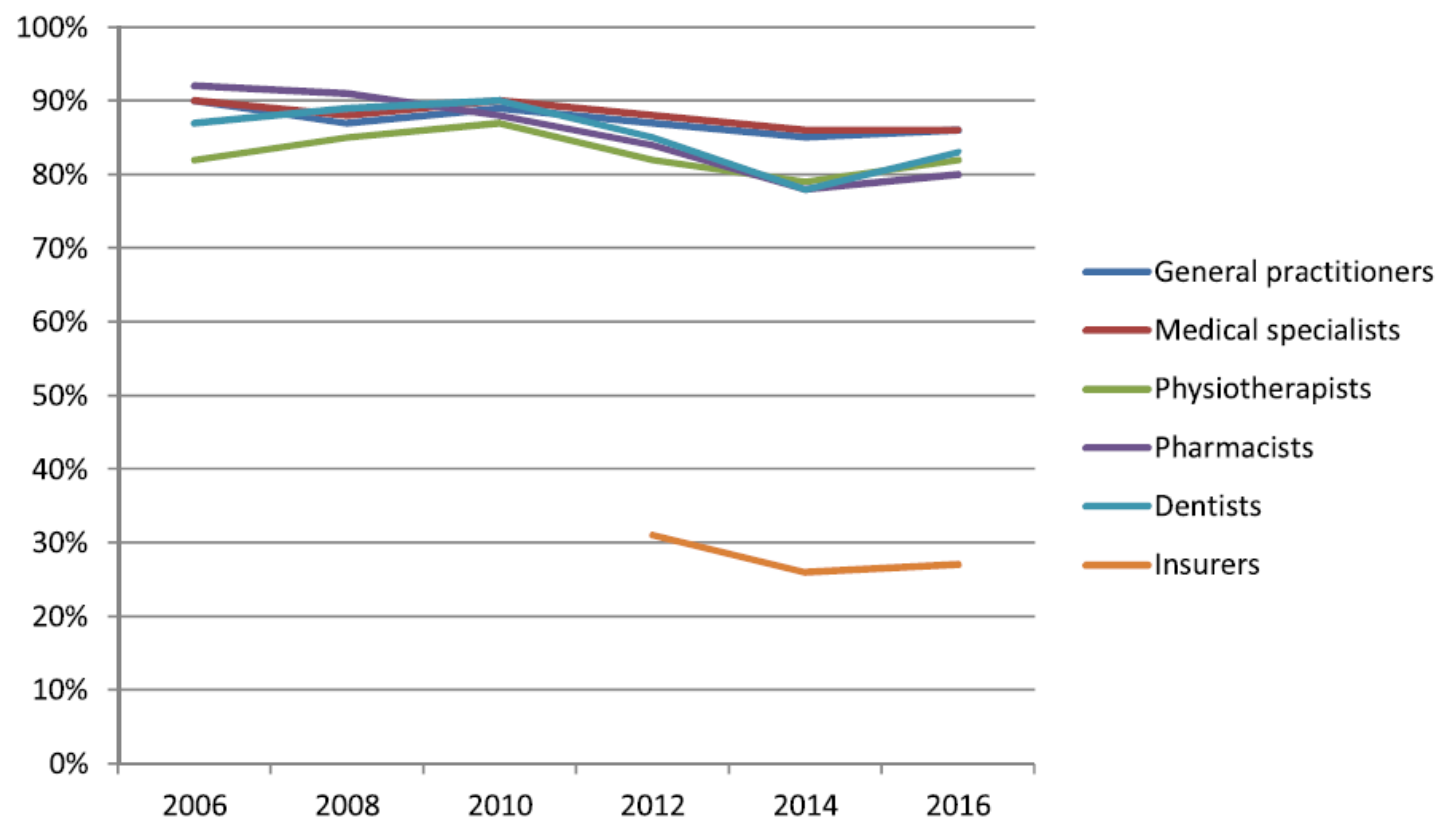

Fig. 1. Percentage of people who place (very) high trust in providers and insurers. 